\title{
Effects of Mass University Enrolment on Non-Academic Activities: The Case of the University of Nairobi, Kenya
}

\author{
Paul A. Odundo, Japheth Origa, Isaiah Nyandega, Boniface Ngaruiya \\ College of Education and External Studies, School of Education, University of Nairobi, Nairobi, Kenya
}

Email address:

odundopaul@yahoo.com (P. A. Odundo)

\section{To cite this article:}

Paul A. Odundo, Japheth Origa, Isaiah Nyandega, Boniface Ngaruiya. Effects of Mass University Enrolment on Non-Academic Activities: The Case of the University of Nairobi, Kenya. Education Journal. Vol. 4, No. 2, 2015, pp. 51-59. doi: 10.11648/j.edu.20150402.11

\begin{abstract}
Public universities in Kenya have recorded high enrolment rates in the past two decades due to pressure from the expanded primary and secondary education and increased demand for university education among the working population. At the University of Nairobi, the rapid growth of student population has resulted in a number of challenges, including inadequacy of physical, human and financial resources. Recognizing the critical contribution of non-academic activities such as administrative procedures, financial governance and student quality of life, to academic performance and research achievements in any university, this study investigated the impact of high student enrolments (referred to in this paper as massification) on non-academic activities at the University of Nairobi. The study used both primary and secondary data; primary data were collected through in-depth interviews with university staff, whereas secondary data were obtained from departmental records and key policy documents. The study found that massification had resulted in numerous administrative challenges, financial and governance challenges, and affected the quality of on-campus life for students due to overstretched accommodation, health, catering and games facilities. To address the challenges, the university implemented a number of initiatives including, devolution of funds to cost centres, double-decking and universal computerization to increase efficiency. The study recommends the need for more responsive administrative structures.
\end{abstract}

Keywords: Mass University Enrolment, Non Accademic Activities, Massification of University Education, Institutional Managament, Student Quality of Life, Financing

\section{Introduction}

University education is an indispensable element for socioeconomic, political and technological development world over (Republic of Kenya, 2005a; Republic of Kenya, 1998; Psacharopoulos, 1985). Access to University education is not only one of the fundamental rights of an individual but also, and more importantly, a crucial tool for sustained socioeconomic development and an important exit route from poverty (Republic of Kenya, 2003a; 2005a). It therefore, plays a crucial role towards achievement of a life of dignity and prosperity for all citizens. Besides, increased investment in education, particularly at the university level is the most fundamental path to realization of the Millennium Development Goals (MDGs) (Republic of Kenya, 2005a). The idea for a national institution to provide university education was conceived in the 1950s. Before then, university education was sought from either Europe or the then Makerere College in Uganda. The first tertiary education institution was set up in Kenya in 1956 and named the Royal College of Nairobi. In 1961, the Royal College entered a special relation with the University of London, through which it began to offer degree courses in Arts and Science. In 1964, it became the University College, Nairobi, which, in 1970 was transformed to a fully-fledged institution through an Act of Parliament and named the University of Nairobi.

Since its inception, the University of Nairobi has continuously reviewed its administrative structures and academic programmes in response to the funding trends, the need to improve efficiency and effectiveness in service delivery, as well as job market dynamisms. By 2006/2007, the University had six colleges, including the College of Education and External Studies (CEES), the College of Architecture and Engineering (CAE), the College of Biological and Physical Sciences (CBPS), the College of Health Sciences (CHS), the College of Agriculture and 
Veterinary Sciences (CAVS) and the College of Humanities and Social Sciences (CHSS). Besides, the institution had four faculties, 16 Schools, six institutes and two centres. At the undergraduate level, the University provided a variety of programmes leading to bachelors' degree qualification. The programmes were offered in two modules, module one for the regular students and module two for self-sponsored students. Furthermore, the University offers postgraduate studies which lead to Master of Arts (MA), Master of Science (MSc) and Doctor of Philosophy (PhD) degrees as well as Postgraduate Diploma (PGD) qualifications.

\subsection{Enrolment}

By 2006/2007, the University of Nairobi had a total of 39,994 students enrolled for regular and self-sponsored (parallel) programmes, both at the undergraduate and postgraduate levels. Of this figure, 7,573 were postgraduate students. Among postgraduate students, those enrolled for regular programmes were $1,731(22.9 \%)$, while the selfsponsored were 5,842 (77.1\%). The 2006/07 data also indicated that the University had a total of 32,421 undergraduate students. Of this figure, 12,648 (39\%) were regular students, while the majority, [19,773 (61\%)], were enrolled for self-sponsored programmes. A critical point is that the upsurge of enrolment due to self-sponsored programmes has exerted even more pressure on the available physical and human resources.

\subsection{Academic and Support Staff}

In the 2006/07 academic year, the University had a total workforce of 4,397 academic and non-academic employees. Of this figure, $1,249(28.4 \%)$ were academic staff, while $3,148(71.6 \%)$ were non-academic workers. Among the academic workforce, the majority [947 (75.8\%)] were men, while $302(24.2 \%)$ were women. Besides, among the nonacademic staff, were $1,922(61.1 \%)$ men against 1,226 $(38.9 \%)$ women. The staffing situation at the University of Nairobi was characterized by serious imbalances among departments and faculties, mainly due to defective staffing norms that were also slow to respond to massification. Although permanent staff were the majority, there was a rising trend of those on contract and temporary terms. Among the colleges, the CHS was the most endowed with academic staff, followed by the CHSS. The most understaffed college was the CEES, with only 48 permanent, 11 contracted and 1 temporary staff.

\subsection{Objectives of the Study}

The broad objective of this study was to assess the effects of mass enrolment on the physical, financial and human resources at the University of Nairobi. The exercise was intended to provide useful information that could facilitate the improvement of institutional management, financing and student welfare at the institution. Specifically, the study set out to:

i). Assess the effects of mass enrolment on institutional management and governance, financing, and student quality of life.

ii). Identify and document the innovative measures adopted to address or cope with the challenges posed by massification on the areas in $\mathrm{i}$ above.

\subsection{Significance of the Study}

The University of Nairobi has been staggering under the weight of massification, which began way back in the mid 1980s, intensified in the 1990s and worsened at the dawn of the new millennium. Despite this experience, no comprehensive study has ever been done to assess the impact of massification on non-academic activities, and generate viable recommendations for policy process. In view of this, the study was initiated to identify the non-academic challenges emanating from holding a huge student population and measures instituted to address the challenges or cope with the situation. The study culminated into useful recommendations to inform the policy process and university education programme management.

\section{Methodology}

Primary data were sourced through in-depth interviews with university staff. Secondary information and quantitative data were sourced through desk review of essential national, sectoral and institutional policy documents, including the National Development Plan, Sessional Paper No. 1 of 2005 on A Policy Framework for Education, Training and Research, the Kenya Education Sector Support Programme (KESSP), the Master Plan for Education and Training, 1997-2010 and the Comprehensive Education Sector Analysis Report. At the institutional level, the documents reviewed included University of Nairobi Strategic Plan, 2005-2010, the Students' Welfare Authority Strategic Plan, 2005-2010, the Annual Financial Reports, Unpublished File Records from the Board of Postgraduate Studies and other Departments. The study applied purposive sampling to select respondents including University officials in key policy, administrative and operational positions, directly or indirectly linked to the academic and social needs of students. The qualitative information were organized following key thematic areas. The second step involved description of the responses to produce interim reports; areas that required additional information were identified and the requisite data sourced. The third step involved systematic analysis and interpretation of the interim reports. Quantitative data were processed, verified and tabulated using Microsoft Excel package. 


\subsection{Enrolment Trends}

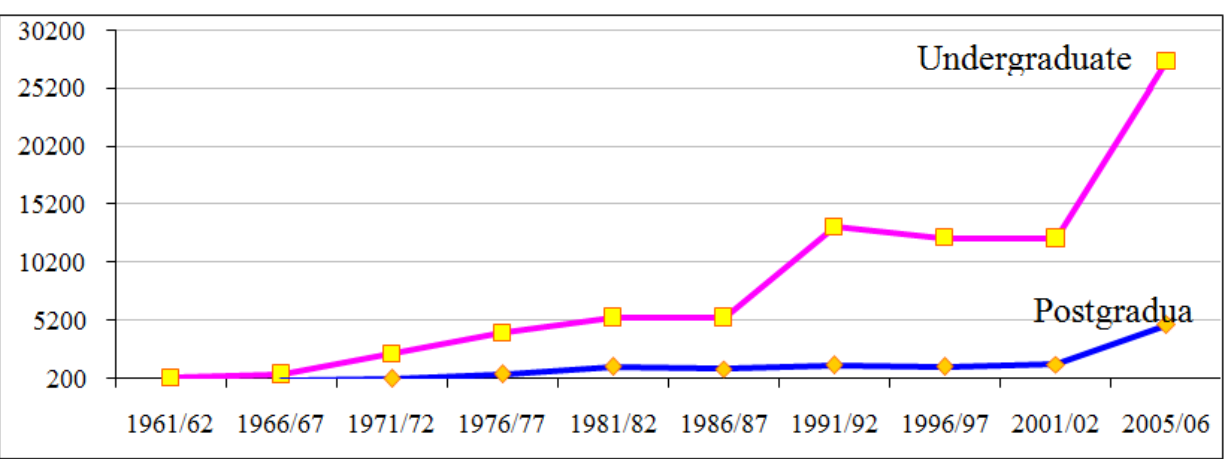

Figure 3.1. The Overall Enrolment for Post and Undergraduate Students, 1961-2005.

Table 3a. The Overall Enrolment for Post and Undergraduate Students.

\begin{tabular}{lllllllllll}
\hline Programmes & $\mathbf{1 9 6 1 / 6 2}$ & $\mathbf{1 9 6 6 / 6 7}$ & $\mathbf{1 9 7 1 / 7 2}$ & $\mathbf{1 9 7 6 / 7 7}$ & $\mathbf{1 9 8 1 / 8 2}$ & $\mathbf{1 9 8 6 / 8 7}$ & $\mathbf{1 9 9 1 / 9 2}$ & $\mathbf{1 9 9 6 / 9 7}$ & $\mathbf{2 0 0 1 / 0 2}$ & $\mathbf{2 0 0 5 / 0 6}$ \\
\hline Undergraduates & 234 & 557 & 2353 & 4098 & 5460 & 5480 & 13248 & 12313 & 12271 & 27498 \\
Postgraduates & - & 44 & 200 & 578 & 1208 & 1026 & 1358 & 1225 & 1451 & 4807 \\
\hline
\end{tabular}

Source: Kenya Annual Statistical Abstracts 1961 - 2006

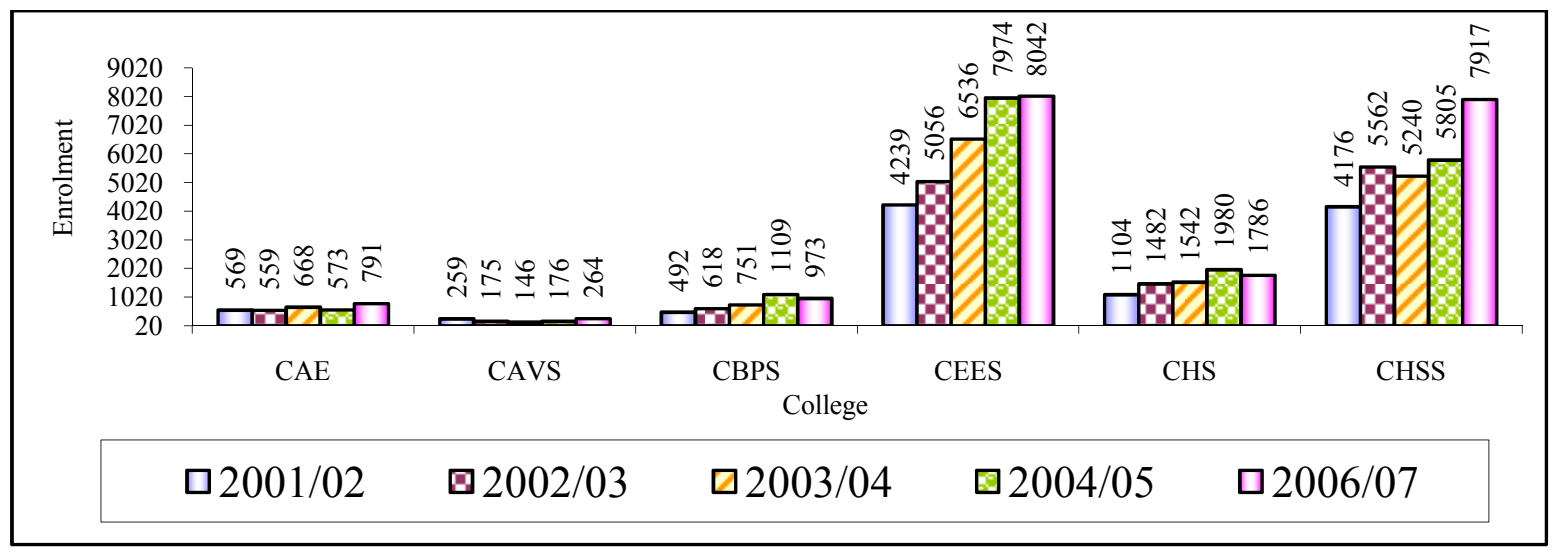

Figure 3.2. Distribution of the Undergraduate Students in Self-sponsored Programme 2001-2007.

Table 3b. Distribution of the Undergraduate Students in Self-sponsored Programme 2001-2007.

\begin{tabular}{llllllll}
\hline Academic Year & CAE & CAVS & CBPS & CEES & CHS & CHSS & Total \\
\hline $2001 / 02$ & 569 & 259 & 492 & 4239 & 1104 & 4176 & 10839 \\
$2002 / 03$ & 559 & 175 & 618 & 5056 & 1482 & 5562 & 13452 \\
$2003 / 04$ & 668 & 146 & 751 & 6536 & 1542 & 5240 & 14883 \\
$2004 / 05$ & 573 & 176 & 1109 & 7974 & 1980 & 5805 & 17617 \\
$2006 / 07$ & 791 & 264 & 973 & 8042 & 1786 & 7917 & 19773 \\
\hline
\end{tabular}

Source: UoN Unpublished File Records, 2001- 2007

The massification of higher education in Kenya arose from deliberate public policy measures to expand accessibility to primary and secondary education right from independence. In this regard, a large proportion of the education budget had, over the years, been channeled to develop and expand primary and secondary education. As a result, the University of Nairobi experienced three occasions of sudden rise in student population. The first one took place in 1986/87 academic year, during a double intake to clear the backlog occasioned by the 1982 coup attempt. Another rapid upsurge in student population was experienced in the 1990/91 academic year, a dual intake of students from the out-going
$7-4-2-3^{1}$ and the in-coming $8-4-4^{2}$ systems. In response to dwindling budgetary allocations from the Government, in the $1997 / 98$ academic year, the University opened its doors to self-sponsored degree and diploma students, as a way of raising funds to bridge the gap. This new development was probably the most important change the University

1 Seven years in primary level, four years at Ordinary level secondary education, two years at the Advanced level secondary education and three years at the University.

2 Eight years of primary education, four years at the secondary tier and four years of University education. 
experienced in its history, because it stimulated the largest enrolment ever seen in the institution's history. Figure 3.1 and Table 3a, show the general trend of enrolment for post and undergraduate students since independence.

Prior to the 2001/02 academic year, postgraduate enrolment increased marginally. The sharp increment after the 2001/02 academic year was due to the open door policy for self-sponsorship, which brought on board students from Kenya and other parts of the world. In the case of undergraduate students, sharp increments were experienced between the 1986/87 and 1991/92 academic years. These were attributed to the double and dual intakes, respectively. A rapid expansion of self-sponsored programmes and growth of student numbers began in the year 2002. Among the colleges, Figure 3.2 and Table $3 \mathrm{~b}$ indicate that the CEES was the most populated with self-sponsored students, followed closely by the CHSS, CHS, CBPS, CAE and CAVS in that order.

The rapid increment in student population had over-taken the University's physical and human infrastructure. Although the self-sponsored programmes boosted the income, a substantial proportion was directed towards construction of buildings and servicing debts that had accumulated since the exchequer allocations began to shrink. Consequently, investments in the expansion of new physical facilities and human resource had not progressed at a rate that would offset the unmet needs. In view of this, massification affected the management and governance, financing and the general welfare of students. These challenges have been highlighted in the following sub-sections.

\subsection{Effects of Massification}

\subsubsection{Institutional Management and Governance}

The sudden increment in students' enrolments had resulted in additional administrative challenges to the University of Nairobi's governance structures. The challenges cited included, meeting the expanding need for infrastructure, sourcing of academic staff, staff welfare and remuneration, meeting training needs of staff and addressing students' welfare issues in time to uphold tranquillity. Other issues pointed out included management of registration, fees collection, inadequate and inappropriate lecture rooms for increased student population, inadequate staff and management of lecture schedules among others. Additional challenges included, managing the disciplinary process and addressing increasing discontent among staff on low remuneration against the increasing workload. The study noted that the administrative demands had increased with the upsurge of students in self-sponsored programmes. This is because while in regular programmes, registration was done once a year; in self-sponsored programmes it was done three times a year. In addition, while the registration of regular students lasted for only one week, that of self-sponsored students continued throughout the semester.

\subsubsection{Financing}

The University of Nairobi has over the years been financed by the Kenyan government. However, the effects of declining economic performance and harsh donor conditionalities have made it difficult for the state to adequately fund university education. The amount granted has persistently fallen below the University's recurrent budgetary estimates. In the 2005/06 financial year, for instance, the University received Kshs 3.2 billion (US\$ 49 million). This was against a budget of Kshs 4.8 billion (US\$ 74 million). As indicated in Figure 3.3, the gap between government funding and the institution's budgetary requirements began emerging way back in the late 1980s. Although the gap has been widening each year, it worsened between 2001/02 and 2005/06 financial years.

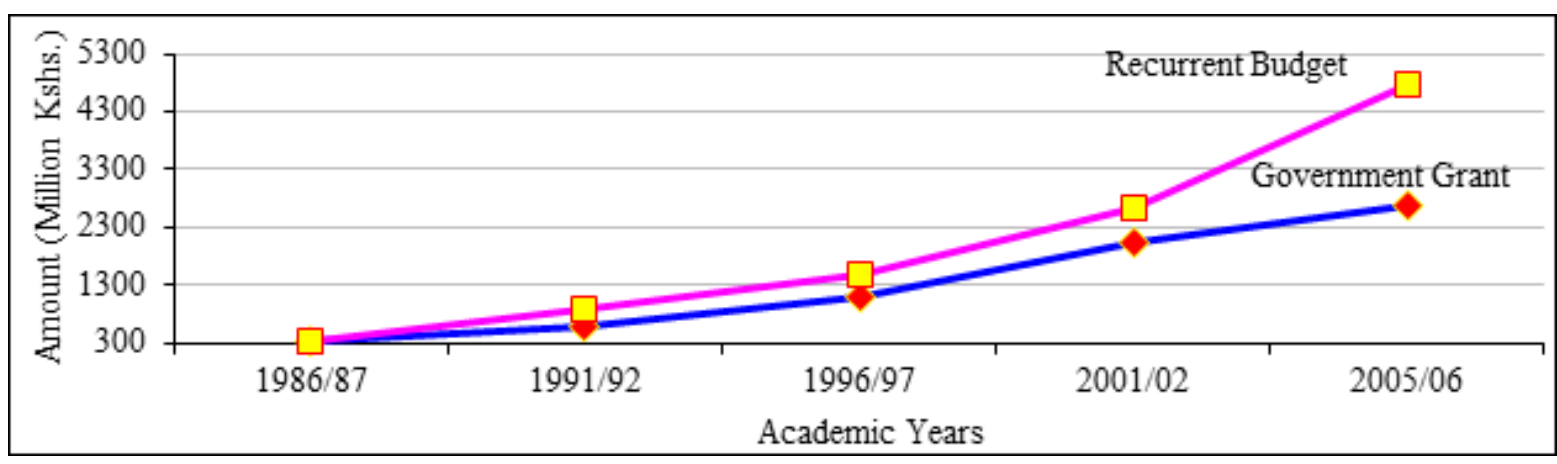

Figure 3.3. Government Grants versus Recurrent Annual Budget, 1986-2006.

Source: Annual Reports and Accounts, 1986 to 2006

In the 1986/87 financial year, government grants exceeded the annual budgetary requirements; in 1991/92, the funds covered only $66.5 \%$ of the budgetary requirements. While in $1996 / 97$, the grants funded $75.5 \%$, improving slightly to $77.8 \%$ in the 2001/02 financial year. However, in the 2005/06 financial year, the grants reduced drastically to cover only $55.5 \%$ of the University's budget, reflecting a budgetary deficit of $45.5 \%$.
The discordance between government funding and the rising enrolment had impacted negatively on development and operations of the University. For instance, most capital development projects such as buildings, roads, parking lots, electrical installation, water installation, sewage and fencing stalled or were postponed. Further assessment of financial reports noted that the University's annual recurrent budget had 
been rising over the years and so was the annual income. The study noted that the bulk of the University's income came from the exchequer. In this regard, Figure 3.4, shows that for a long time, self-generated income remained below Kshs 500 million (US\$ 7.7 million) per year. The Income Generation Units
(IGUs) began to flourish after 2001/02 financial year; and selfgenerated income increased sharply thereafter. By 2005/06 financial year, the University was generating over Kshs 2 billion (US\$ 31 million) while the government funding stood at Kshs 2.8 billion (US\$ 43.1 million).

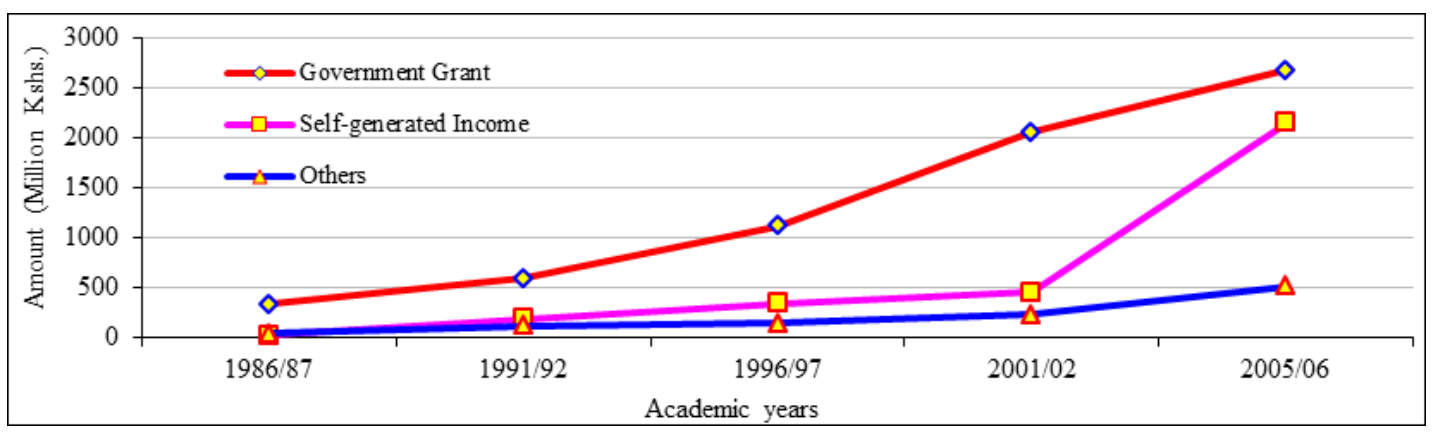

Figure 3.4. Grant from the Government and Self-generated Income, 1986-2006.

Source: Data obtained from the Annual Reports and Accounts

Other sources of funding included endowment and trust funds as well as research grants from various organizations and individuals. However, as indicated in the figure, annual receipts from the named sources remained minimal over time. Improvement began in 2001/02 financial year; and in 2005/06, the University received a total of Kshs 508 million (US\$ 7.8 million), as endowment trust and research funds. The income generating activities included self-sponsored programmes, research and consultancy, farming and funeral services (mortuary). At the central administration, income generating activities included real estate development, University Health Services, library services, bookshop, printing press, renting halls, games facilities and catering services, among others.

\subsubsection{Students' Quality of Life}

The accommodation facilities were issued to regular undergraduate students, as a first priority. Although selfsponsored students were often advised to seek accommodation off-campus, the escalating enrolment exerted continuous pressure on the University to absorb them. The accommodation policy assumed that all self-sponsored students were financially able to rent private accommodation off-campus. Although enrolment had grown from 5,568 students in $1986 / 87$ to 32,421 students in $2006 / 07$ academic year, bed space increased by 6,591 (118\%) from 5,600 in $1986 / 87$ to 12,191 in the $2006 / 07$ academic year. The pressure for accommodation was mainly experienced at the Main, Chiromo and Parklands Campuses. In addition, the number of students floating without official accommodation on-campus was on the rise due to massification. Some students made informal arrangements to share the cost of accommodation so that they could save some money for subsistence. The economic implications of the practice were huge on the University's recurrent budget, particularly on utility bills. Another challenge was cooking in the rooms. The practice had serious implications on finances of the institution, including high electricity bills and the cost of maintaining drainage systems as well as power sockets. Other effects included poor state of hygiene in halls, fire incidences and resentment among students. The University Health Services (UHS) had suffered its share of the burden of rapid increment in student population. This was experienced in terms of heavy workload, a diversity of health issues, as well as high frequency of illnesses due to congestion in the rooms. Notably, workload had increased from about 30-50 students per day in the early 1990 s to over 200 students per day. The large number of students in need of healthcare services caused long queues and enlengthened the queuing time before services were rendered. This in turn, aroused numerous complaints, anxiety and frustrations among the students. The heavy workload exerted pressure on healthcare staff, forcing them to work longer hours without extra allowances.

\section{Approaches to Address the Non- Academic Challenges of Massification}

\subsection{Institutional Management and Governance}

\subsubsection{Computerization}

To cope with heavy administrative work, the University computerized all its administrative units at the departmental, faculty, college and central administration levels. This improved the level of efficiency in handling administrative processes such as admission, registration for programmes and examination processing. For instance, unlike a few years ago, all faculties generated transcripts and other student data using ICT systems with superior packages such as Students Information Management System (SIMS). In this regard, cases of missing marks were no longer experienced. To ensure effectiveness, the University organized for internal training, facilitated by the School of Computing and Informatics. Computerization also enabled the administrative systems to track fee balances and access student information conveniently. 


\subsubsection{Training in Management and Governance}

To improve efficiency in management and governance, the University stepped up training for personnel in administrative and management at all levels with a view to adopting modern management practices. A major achievement for this training programme was that of Deans, Directors and Chairmen of Departments as well as Examination Officers, which was done in 2006. The trainings were initiated and implemented by senior staff and each session lasted for about a week. Through trainings most administrative and management staff became more efficient and more responsive to student needs.

\subsubsection{Administrative Reforms}

At the time of the study, the University was undergoing numerous reform processes aimed at improving service delivery in all spheres. This was based on the realization that the University required highly dynamic and motivated managers to effectively cope with the diverse needs of students. To begin with, the University was the first institution of higher learning in the country to recruit its Vice Chancellor through a transparent and competitive process. This had been extended to cover even principals of colleges and their deputies. Related to this move was the consolidation of meritocracy in creating highly motivated teams with a passion for effective performance. To achieve this, there was a tendency to move towards contractual performance, standards and excellence. The results of these approaches included improved discipline among staff and students, higher efficiency in handling student affairs, tranquillity among student community and improved financial performance.

\subsubsection{Strategic Planning}

Further, the University developed a strategic plan for the 2005-2010 period. This enabled the institution to progress in a structured and measurable manner. Since its launch in 2005, the University had made great strides in achieving targets set out in the plan. Through bottom-up approach, the planning process began at the departmental level. In this regard, academic and non-academic departments prepared their strategic plans, which were then consolidated into the main plan for the entire institution. This approach ensured that strategic issues identified in the main plan reflected the actual issues arising from various departments and sections of the institution. The main plan lays out an implementation schedule to address the challenges and expedite realization of the institutional vision and mission.

\subsubsection{Service Charter}

In 2006, the University launched its service charter, which outlined the services rendered under specific timelines. The Charter also committed the staff to offer timely, quality service to the clientele. This move ensured prompt delivery of services to students and other cadres of clientele.

\subsubsection{Staff Appraisal}

On performance management, the University institutionalized staff performance appraisal as an annual exercise. In 2006, a ceremony was held to award outstanding members of staff, based on the new appraisal system. It was anticipated that future employment dynamics would be pegged on the appraisal system. This move motivated staff to work harder, improved sense of belonging and changed attitude towards service delivery.

\subsubsection{Devolution of Management Functions}

The University operated within a policy framework, where authority, responsibility and accountability were devolved to various levels of the administrative system. The chairmen of departments were mandated to ensure that University procedures and regulations, including provisions of the University Act and Statutes were observed. At the faculty level, administrative work involved co-ordination of departmental activities. More still, faculties developed new academic programmes and coordinated timetabling for both teaching and examinations. Colleges were set up to link the faculties, institutes, schools and academic departments with the University administration. Among other functions, colleges coordinated all the activities of faculties, institutes, centres and schools. The devolved administrative structure ensured timely response to students' academic, psychosocial and financial needs.

\subsubsection{Involvement of Students in Administrative System}

The University had incorporated students' leadership in all key decision-making organs including the university's governing Council. In this regard, channels were created for student leaders to inform the administration about issues affecting students for timely redress. This yielded positive results where students shunned violence and threats, as a means to achieve their objectives. By rejecting confrontational politics in favour of dialogue, the student leadership was able to work with the administration more effectively to create a peaceful learning environment.

\subsubsection{Performance Contracting}

In 2006, the University put all its six colleges on performance contracts. The contracts contained a number of performance targets to be achieved within the 2006/2007 contract year. The college performance contracts derived from the University's performance contract, signed with the Ministry of Education in the 2005/2006 financial year. Performance contracts had the following targets: reduction of cost by Kshs 5.4 million (US\$ 83,000); 100\% implement of the Service Charter; increase proportion of students and staff accessing the electronic library resources up to $40 \%$ and $60 \%$, respectively; up to 100 new publications in refereed journals; enhanced ICT facilities and services; $100 \%$ students' discipline; as well as a clean and neat environment.

\subsection{Financing}

\subsubsection{Expanded Income Generation}

The University embarked on expansion and diversification of internal sources of revenue, which included self-sponsored programmes, research and consultancy, farming, funeral services, animal clinics, food processing, irrigation schemes, 
animal and agricultural equipment fabrication workshops. Additional activities included diagnostic radiology, pharmacy practice centre, estate department, bookshop and university printing press. The expanded income generation had enabled the University to: complete some of the stalled projects, rehabilitate and purchase physical facilities, establish and equip a University-wide ICT infrastructure, procure educational materials, purchase utility vehicles, and improve staff welfare.

\subsubsection{Devolution of Funds to the Cost Centres}

To ensure efficiency and timely response to emerging academic needs, funds were devolved to all cost centres including schools, institutes and departments. Also devolved were the Authority to Incur Expenditure (AIE). The votes were held by Directors of Schools and Institutes as well as Departmental Chairs, who had the mandate to control costs in line with expenditure guidelines. As part of devolution, the college-based IGUs were allowed to spend part of the funds generated to improve productivity, as long as this was done in accordance with University's financial regulations. Devolution of funds enabled the cost centres to react faster to pressing needs and reduced delays associated with bureaucratic procedures of seeking funds from the central administration.

\subsubsection{Financial Discipline Measures}

To ensure efficient and effective financial management, the University entrenched financial discipline among its administrators. These included strict full cost recovery, cost reduction and cost control measures. Cost recovery was applied in tuition fees, student accommodation and catering, staff and students' medical scheme among others. Cost reduction measures involved retrenchment of non-academic staff, particularly in the cleaning, maintenance and catering sections. Further, the University made efforts to control the costs of utilities, telephone, stationery and vehicles. These measures enabled the University to improve its annual income from self-generated sources, honour its financial obligations, renovate facilities and revive stalled projects.

\subsection{Student Quality of Life}

\subsubsection{Computerization of Operations}

The management of students' accommodation services suffered from a number of setbacks, including the rising number of students staying on-campus without officially allocated rooms; illegal sub-letting of rooms; congestion and poor sanitation among others. In response to the situation, the operations of Students Welfare Authority (SWA) were computerized in the year 2003. This measure improved efficiency in allocation of rooms, monitoring expenditures, accessing past records and compilation of quick reports. Further, the computerization programme enabled the authority to improve revenue collection by about $85 \%$, as well as efficient utilization of the funds collected.

\subsubsection{Formulation of the HIV/AIDS Policy}

Managing HIV/AIDS related opportunistic infections among students and staff alike formed a serious challenge to the University Health Services (UHS). The UHS spent a substantial proportion of its resources in treating opportunistic infections and supporting clients to obtain antiretroviral drugs. To respond to the situation, the University established an AIDS Control Unit (ACU) in 2002. The Unit sensitised staff and students on HIV/AIDS. It also facilitated the formulation of a comprehensive policy on HIV/AIDS to guide preventive and curative initiatives. In this regard, students were reminded to lead responsible lives by avoiding unprotected sexual activities. Condoms were provided free at the University Health Services. Students were also encouraged to utilize the campus-based Voluntary Counseling Testing (VCT) facility. The response to HIV/AIDS pandemic had helped improve the level of awareness; promoted mainstreaming of HIV/AIDS activities by various students groups; and behaviour change among the student community.

\subsubsection{The Students' Organization}

The University had experienced numerous occasions of students' unrest, particularly in the 1990s. These led to destruction of property within the vicinity and disruption of academic calendars through unscheduled closures. Some of the unrests were attributed to lack of channels to permit students to air out issues affecting them to the university administration. In response to this, the Students Organization of Nairobi University '98 (SONU '98) was re-registered in 1998 after being banned in 1982 for taking part in the attempted coup. Through SONU '98, students' leadership was mandated to channel issues affecting students to the university administration. The organization ensured that students were given quality facilities as well as peace and tranquillity for a conducive learning environment.

\subsubsection{Ensuring Security on Campus}

The infiltration of some members of the public in residential halls raised numerous security issues, including, theft of clothing and electronic assets. In response to the situation, the university established a security department mandated to safeguard and protect all students, members of staff as well as personal and university property. To control the movement of students and visitors in the residential areas, each hall had a reception desk, where all visitors were required to register before seeing students in their rooms. Since the measures were introduced, the frequency of theft cases had reduced considerably. In addition, at the women's halls, there was a rule of " 10 to 10 ", which meant that no visitor was allowed to visit women's residences before 10.00 $\mathrm{am}$ in the morning and after $1.00 \mathrm{pm}$ in the night.

\section{Summary, Conclusions \& Recommendations}

The rapid increment in student population at the University of Nairobi may be attributed to three main factors, namely the pressure from the expansion of primary and secondary 
education; the need to generate financial resources to offset the funding gap created by dwindling support from the exchequer; and the rising need to upgrade qualifications among employees of public, corporate and NGO sectors. Free primary and subsidized secondary education have affected the university in two ways; first, by reducing its budgetary allocation and second, by increasing the pressure for admission. In this regard, the university will have no option but to admit as many students as possible in selfsponsored programmes to bridge the financial gap. Still, due to the changing job market, where retention and promotions are increasingly depending on postgraduate qualifications, rapid growth in student population at the university is inevitable. More pressure which will be building from within the education sector and that from the job market should be expected to increase. The university must gear up to face the challenge.

In view of the anticipated increase in demand for university education, the current administrative, management and governance systems are not likely to withstand the pressure of future enrolments. To ensure quality academic services and to cash in on the high demand, especially from the free primary and secondary education, the university must expand its infrastructure to maintain if not expand its market share in higher education through self-sponsored programmes. Further, the experiences of the past two decades show that rapid increment in student population has serious implications on the university's operations in administration, management, governance, finance, and student welfare. Although a number of coping measures have been instituted, the university has not been able to address these issues effectively and adequately. Though non-academic, these affect the university's academic and research outputs.

In addition, the past experience shows that managing a large population of students is not an easy task. It requires more resources to ensure efficiency and effectiveness. The use of ICT facilities is likely to improve management and administrative work immensely, which in turn will expedite realization of targets and goals. Although the university has made some effort to embrace ICT in management, a lot more must be done, particularly in view of the expected growth. Beside, even though massification came with numerous challenges, the large number of students in self-sponsored programmes has played a big role in turning a round the institution's financial position. The university has not made much profit from the programmes, but there are prospects for a brighter future. This attest to the fact that if well managed, massification of higher education, will change the future of many universities in Africa.

\subsection{Administrative Structures}

The university should continue with the restructuring programme aimed at making the administrative units more responsive to the needs of students. Other departments such as the Department of Extra-Mural Studies should be supported to proceed with the intended restructuring programme and become a School of Open and Distance
Learning. In addition, the restructuring programme should target the Board of Postgraduate Studies (BPS) to promote postgraduate studies. Graduate programmes should be expanded and repackaged to be in line with market demands. Such reforms, it was noted, would market the institution and make it a truly world class university in line with its vision.

\subsection{The University Database}

It is imperative that the university takes urgent measures to computerize the database for quicker access and utilization to inform the decision-making processes. This is based on the realization that most data in the university's archives are not easily accessible.

\subsection{Academic Staff}

The university needs to source academic staff. This will give adequate staff welfare and remuneration, meeting the training needs of staff.

\subsection{Students' Welfare}

There should be an effective way to solve the students' issues to uphold tranquillity. Hence, avoiding escalation of unresolved conflict.

\section{References}

[1] Albrecht B. (1992). Differed Cost Recovery for Higher Education: Student Loan Programmes In developing countries. World Bank Discussion Paper No.137. Kenya,

[2] Best, J.W. and Khan, J.V. (2004). Research in Education, $7^{\text {th }}$ Edition. New Delhi: Prentice Hall of India.

[3] Digolo, O. (1993). Problems of Rapid Expansion at the University Level, in Status of Teachers in Kenya: National case Study of the Government of Kenya, UNESCO and ILO. Nairobi, pp 116-123.

[4] Kenya, Republic of, (1998). Master Plan for Education and Training, 1997-2010. Nairobi: Government of Kenya.

[5] Kenya, Republic of, (2003a). The Economic Recovery Strategy for Wealth and Employment Creation 2003-2007. Nairobi: Government of Kenya.

[6] Kenya, Republic of, (2003b). Millennium Development Goals: Progress Report for Kenya. Nairobi: Government of Kenya.

[7] Kenya, Republic of, (2005a). Sessional Paper no. 1 of 2005: Policy Framework for Education, Training and Research. Nairobi: MoES\&T.

[8] Kenya, Republic of, (2005b). Kenya Education Sector Support Programme (KESSP). Nairobi: MoES\&T.

[9] Kenya, Republic of. (2002). National Development Plan 2002-2008. Nairobi: Government Printer

[10] Mugenda, O.M. and Mugenda, A.G. 1999. Research Methods: Quantitative and Qualitative Approaches. Nairobi: Act Press.

[11] Mwiria, K., Ng'ethe, N., Ngome, C., Ouma-Odero, D., Wawire, V., and Wesonga, D. (2007). Public and Private Universities in Kenya. Nairobi: East African Publishers. 
[12] Ngome, C. (2003). African Higher Education: An International Reference Handbook in Teferra, D. and Philip. G. Altbach, eds., Indiana: Indiana University Press.

[13] Njeru, E.H.N. and Orodho, J.A (035/2003). Education Financing in Kenya: Secondary School Bursary Scheme Implementation and Challenges. Nairobi: IPAR.

[14] Psacharopoulos, G. (1985). Returns to Education: A Further International Update and Implications. Washington DC: World Bank.

[15] Republic of (1988) Sessional Paper No. 6: Education and Manpower Training for the Next Decade and Beyond. Nairobi: Government Printer.
[16] UNES (2005). Corporate Strategic Plan, 2005-2010. Nairobi: Nairobi: University of Nairobi Press.

[17] United Nations (2000). The Millennium Development Goals. New York. United Nations

[18] University of Nairobi (1995). Proceedings of Management Seminar for University of Nairobi Administrators. Nairobi: University of Nairobi Press.

[19] University of Nairobi (2005). Strategic Plan, 2005-2010: Towards World Class Excellence. Nairobi: University of Nairobi Press. 